\title{
LINGUISTIC FEATURES OF EVALUATIVE STANCE: FINDINGS FROM RESEARCH ARTICLE DISCUSSIONS
}

\author{
Attapol Khamkhien \\ Department of English, Faculty of Liberal Arts and Science, Kasetsart University. Thailand \\ email: faasapk@ku.ac.th
}

\begin{abstract}
Recent research (e.g., Hunston 2007; Hyland 1999; 2008; 2009) has marked and evidenced the importance of effectively using linguistic features as a major component in expressing stances and as an essential part of the shared knowledge of a professional discourse community by giving space for negotiation and evaluation of viewpoints. The present study is concerned with the use of the expression of evaluation in academic discourse, focusing on some communicative strategies for indicating stance. With the corpus-based approach, research articles on applied linguistics and language teaching selected from top-ten journals were systematically complied and analyzed. The results revealed that professional and experienced writers variably exploit stance markers including epistemic modality, extraposed 'it', communication verbs, and personal pronouns in terms of different functional types of evaluative stance. The findings highlight the importance of understanding the use of stance devices in academics, facilitating a better understanding of novice readers and writers when writing academic productions. Pedagogically, the description of this study contributes to ways to improvement of practical language and academic writing courses to suit the discourse community.
\end{abstract}

Keywords: Corpus, evaluative stance, discourse, academic research

\section{FITUR-FITUR KEBAHASAAN DARI SUDUT PANDANG EVALUATIF: TEMUAN DARI DISKUSI ARTIKEL PENELITIAN}

\begin{abstract}
Abstrak: Penelitian terbaru (seperti, Hunston, 2007; Hyland, 1999; 2008; 2009) telah menunjukkan dan membuktikan pentingnya penggunaan fitur-fitur kebahasaan secara efektif sebagai komponen utama dalam mengekspresikan sudut pandang dan sebagai bagian penting dalam berbagi pengetahuan dari sebuah komunitas wacana profesional dengan memberikan ruang negosiasi dan evaluasi terhadap cara pandang. Penelitian ini berkaitan dengan penggunaan pernyataan-pernyataan evaluasi dalam wacana akademik, yang fokus pada beberapa strategi komunikatif untuk menunjukkan sudut pandang. Dengan menggunakan pendekatan berbasis korpus, artikel-artikel jurnal dalam bidang linguistik terapan dan pengajaran bahasa yang disaring dari sepuluh jurnal terbaik dikumpulkan dan dianalisis secara sistematis. Hasil penelitian ini mengungkap bahwa penulis yang profesional dan berpengalaman banyak menggunakan penanda sudut pandang, seperti modalitas epistemik, ekstraposisi "it", kata kerja komunikasi, dan kata ganti benda personal secara bervariasi dalam hal jenis-jenis sudut pandang evaluatif fungsional yang berbeda-beda. Temuan dalam penelitian ini menyoroti pentingnya pemahaman terhadap penggunaan perangkat penanda sudut pandang di bidang akademis, untuk memfasilitasi pemahaman yang lebih baik bagi para pembaca dan penulis pemula ketika menulis karya bersifat akademis. Secara pedagogis, paparan dalam penelitian ini memberikan kontribusi terhadap perkembangan bahasa praktis dan mata kuliah menulis akademis yang sesuai dalam komunitas wacana tertentu.
\end{abstract}

Katakunci: Korpus, sudut pandang evaluatif, wacana, penelitian akademik 
English is considered to be the most important world language (Crystal, 1997). It is used in every domain of communication professionally and scholarly, particularly in higher education worldwide. It has become one of the main tools for distributing advanced knowledge from studies among scholars worldwide through research articles. To be precise, a research article is a piece of published writing which aims to share the knowledge in the discipline and in the educational field. In this regard, in English Language Teaching (ELT), the role of academic journals is more prominent, as witnessed by their frequent publications. In order to facilitate the reading and/ or writing of research articles, both native and nonnative speakers of English need to be aware of the language style conventionally used in their respective fields of interest.

Traditionally, English academic writing has been thought of as a convention-bound monolithic entity that involves distant, complex and impersonal prose (Ivanic, 1998). A common perception of academic text is that its main purpose is to present information in an objective and impersonal way, as characterized by lexico-grammatical features such as nominalization and the passive voice, compared to casual conversation. Therefore, total avoidance of a writer's presence or presenting the information in impersonal way is required in academic writing. However, as opposed by Kanoksilapatham (2005), language, be it spoken or written, is complex, reflecting an interaction and manifestation of linguistic features conveying a message. Specifically, it contains linguistic devices which can help reader or listener to organize, interpret and evaluate the propositional content (Hyland, 1999; Crismore et al., 1993). In terms of academic writing, Dontcheva-Navratilova (2009) pointed out that academic discourse is as a purposeful interaction between writers and readers in which the writers try to construct a coherent representation to build up a relationship with the discourse community by giving dialogic space for negotiation and evaluation of their views. For decades, thus, there has been increasing number of interests in exploring interaction in discourse specifically written texts that embody interactions between writers and readers as a wide range of linguistic features could contribute to the writers to use or project their stance in their writing.

A number of previous studies (e.g., Hunston \& Thompson, 2000; Hyland, 2005a; Martin, 1997) focusing on interaction between writers and readers in discourse are increasing in the discourse analysis field. For instance, Hunston and Thompson (2000) suggested that writers can express their identity and evaluation through some interactive aspect of discourse, which can be divided into three main functions of evaluation, namely ideational, interactional and textual functions. These three aspects of meanings suggested are correlated with the study conducted by Halliday \& Hasan (1989) positing systemic-functional linguistics. Using the analytical framework of the interpersonal model of metadiscourse, Hyland (2004) also proposed that using hedges and boosters as communicative strategies could convey the writers' degree of confidence in the truth of a proposition and expressing an attitude to the audience. The study illustrated that the use of hedges enables the writers to acknowledge the existence of alternative voices and viewpoints and to withdraw their commitment to the proposition, while the use of boosters helps to close down alternatives and to show a high degree of certainty. Such a study on metadiscourse provides a means of investigating the relationship between academic writers and their readership. The results of these studies reflect that, even though academic writing is usually thought to be impersonal, writers can express their opinion in their 
texts to present their findings and evaluate these findings, and comment on them. Taken together, the choice of linguistic features could reflect a shared world of writer and reader, which is constructed with the ultimate aim of persuading the reader to accept the writer's view. That is, interaction between writers and their reader can be found in the discourse, and at the same time they try to avoid their identities in paper through the linguistic features used in order to follow the traditional way of writing (Hunston, 2000).

With regard to the Discussion section in academic articles, this particular section is important because it conventionally requires authors to express their ideas and opinions, evaluate and compare the results of their studies with the previous studies as it is the space opened for possible reactions of potential readers within their academic community (Kanoksilpatham, 2005). The Discussion section that, to write successfully research articles in English conventionally for academic success of both native and non-native speaker of English, various discourse strategies are substantially needed in order to persuade the audience to accept writers' claims and viewpoints. Therefore, the study of evaluation in the Discussion section in research articles can provide a considerable amount of information about a text. However, studies in this line of research (e.g., Hyland, 2002; Martin, 1997) have also mostly been conducted on a variety of disciplines of research articles and multiple methods, leading to a certain limitation, no overall and clear-cut typology of the resources which the writers employ to express their position and connect with readers. This necessitates further research on leads to the present study. It is hoped that the results of this study would provide a basic understanding for the use of the evaluation by turning them into an explicit statement opinion in writing academic research. It also may be valuable to readers who perceive themselves as having difficulty in understanding what messages are going to be conveyed in this particular section.

Given that the roles of linguistic features in reflecting, constructing ideas and opinions and the importance of the Discussion section in research articles are imminent, the principal objective of this study is to investigate how writers express their evaluative stance through the choice of linguistic features in international academic journals, specifically in the section of Discussion, the section that the writers must evaluate the findings of their study to gain their readers to read on and trust their findings. Specifically, the study seeks to explore linguistic features conveying the meanings of evaluative stance in academic discourse, and the communicative functions of these linguistic features of evaluative stance in research articles.

\section{Academic Writing and Evaluative Stance}

Traditionally, academic writing can be seen as an objective, faceless and impersonal form of discourse. However, over the past decade, a number of research studies on the written texts particularly academic writing (Hunston \& Thompson, 2000; Hyland, 1999; 2005b; 2008; 2009; Hyland \& Tse, 2004), revealed that written texts embody interactions between writers and readers. For instance, as Hyland (2005b: 41) claims, the expression of varying stances towards propositions allows writers not only to position themselves vis à vis the information that they are discussing, but also to position themselves vis à vis a community of readers. These studies also evidenced that a range of linguistic features can be used to contribute to the writer's projection of a stance to the material referenced by the text, to evaluate the information gained from the study, and to a acknowledge alternative views from the previous studies, etc. Consequently, a variety of linguistic resources such as hedges, reporting verbs, that-constructions, 
questions, personal pronouns, and directives have been examined for the role they play in the academic discourse (Hyland, 2000; Hyland \& Tse, 2004).

As the view of evaluation in written texts gains greater interest, more researchers have turned their attention to the concept of evaluation. According to Hunston and Thompson (2000), the expression of a speaker or writer's attitudes, feelings, and values can be expressed in texts, covering areas sometimes referred to as 'stance', 'modality', 'affect', or 'appraisal'. They suggest that evaluation performs three functions. First, it expresses the speaker's or writer's opinion, and in doing so it reflects the value system of that person and their community. Second, it constructs and maintains relations between the speaker or writer and hearer or reader. Third, it organizes the discourse.

As observed by Biber et al. (1999), evaluation conceptually is comparative, subjective, and value-laden. Linguistically, it may be analyzed lexically, grammatically, and textually. The evaluation performs several roles in the discourse as follows: a) it expresses the speaker's opinion and thus reflects the value-system of that person and their community; b) it constructs relations between speaker and hearer (or writer and reader); and c) it plays a key role in how discourse is organized.

Although different definitions of the term evaluation are made, several studies in discourse analysis identified that the patterns of linguistic features could perform communicative functions, including the expression of evaluation of writers in texts (e.g., Hunston \& Thompson, 2000; Hewings \& Hewings, 2002; Kanoksilapatham, 2003). The important findings from these studies agree to reveal some linguistic features used in discourse to perform discourse functions (i.e., extraposed ' $i$ ' and that complement clause, and predicate as communication verbs and adjectives).

\section{“IT" in Discourse}

General grammar books categorize ' $i t$ ' as a pronoun, while in some cases, 'preparatory it' or 'dummy it' are used elsewhere in describing the phenomenon in syntactic level. However, with respect to discourse function, several terms of 'it' are used in observing metadiscoursal function such as it-clause and anticipatory 'it' in discourse analysis studies. The term anticipatory 'it' and extraposed subject are used in the study conducted by Kanoksilapatham (2005). She proposes that those two terms of it-clause in which the subject is placed at the end of the clause on the one hand, and it-clause in which it is inserted in the normal subject position as the grammatical subject in English on the other hand could perform the evaluative stance of the writers.

In Kanoksilapatham's (2005) study focusing on scientific discourse using multidimensional analysis, ' $i t$ ' and extraposed subject provide a means for scientists to express their comments or attitude without making their identification explicit. In this case, extraposed 'it' can be used in two types of complement clauses. That is, that complement clause controlled by predicative adjectives, as well as to complement clause controlled by adjectives. The study also reported that that complement clauses are generally known to index information integration to expand the idea-unit in the dependent clause. Namely, the authors' stance is given in the main clause, and the propositional information is given in the that complement clause.

Jacobs (1995) proposed some problems found in writing and reading a piece of academic writing. Jacob's study identified that the pattern it-clause and that-clause could contribute to problems for non-native speakers as such features of academic writing functioning both to 
express opinions, comment on and evaluate propositions in a way that these markers can allow the writer to remain in the background. These linguistic features draw a conclusion that writers mostly use these linguistic features as strategies to the impression of the presentation of objective, and impersonal knowledge.

In an exhaustive study focusing on evaluation in academic writing, Hewings and Hewings (2002), presented pairs of sentences giving congruent forms in their study, one with extraposed subjects and the other without:

a) That these results are provisional must be emphasized.

aa) It must be emphasized that these results are provisional.

b) To acknowledge the differences is important.

bb) It is important to acknowledge the differences.

The pairs above suggest that clauseinitial 'it' can perform a wide variety of grammatical functions. Congruent with Hewings and Hewings (2002), Biber, Johanson, Leech, Conrad, and Finegan (1999) observed some grammatical features in academic writing, claiming that it-clauses followed by extraposed thatclause as in (aa) are moderately common in academic setting both prose and written news report, but rarely found in fiction and conversation. While it-clauses with an adjective followed by extraposed to-clause as in (bb) are rarely found in conversation, they are moderately common in fiction and written news reports, but common in academic writing.

Another interesting study focusing on the grammatical and communicative functions of extraposed clause constructions was conducted by Rodman (1991), The findings of this study suggested that using ' $i t$ ' is an important strategy in academic writing. Rodman's study revealed that this construction delayed the notional subject and verb. It is also a marked construction used to emphasize the extraposed elements. The study pointed out that, by this structure, 'new' information is presented at the end of the sentence where readers are likely to find it easier to process. Rodman (1991)'s findings are in line with Herriman (2000)'s study. That is, extraposition is beneficial to writers because the structure makes available the means to present attitudinal meanings at the beginning of the clause while concealing the sources of this attitude with an impersonal subject or socalled dummy subject 'it'. This concealment increases the facticity of a statement and provides writers with a means of varying evaluation as an explicit and negotiable proposition.

From these studies, thus, it can be said, in a very broad sense, that both patterns of it-clause-with that complement clause controlled by predicative adjectives, and to complement clause controlled by adjectives, are used as writers' strategies to perform communicative functions and can be found in academic writing. However, they are rarely found in terms of spoken mode of communication. These studies also suggested that the use of it-clause is a strategy to add the impression of the presentation of objective and impersonal knowledge. In addition, as observed by Craswell (2005), in academic writing, the preference of extraposed 'it' over the first person (' $I$ ' or ' $W e$ ') can persuade the readers to believe and thrust that the content that will be expressed after that is objectively presented in the impersonal subject.

\section{Predicate and Adjective in Evaluative Function}

Other linguistic features which can express the evaluative function in discourse are predicate and adjective. In terms of predicate, Biber et al. (1999) pointed out that the evaluative potential of this kind of structure can be introduced by a range of different predicates. Their study suggested 
that, as a common case, writers select a verb to hold the that-clause in the scope of the evaluation. This clause is frequently followed by cognitive or affective verbs such as think, know, and believe, speech act verbs, like say and state, and other communication verbs such as suggest and prove.

A recent study conducted by Hyland and Tse (2005) suggested from the corpus of their study that, that-clause structure highly occurs in research writing after the use of adjectives e.g., confident, unclear, etc. as the examples of the texts as follows:

a) $\mathrm{We}$ are confident that those two variables will suffice to monitor success of $\mathrm{CM}$ implementation. (Electronic Engineering)

b) However, it is unclear that such cost savings are being fully realized since EDLP stores also engage in price promotions. (Business Studies)

The study claimed that these examples lie not only in their formal resemblance on the surface of the discourse, but in their functional kinship, a relationship in which different uses cohere around a core meaning of evaluation represented. Thatclause is a site where the writers must foreground their main claims and evaluation as a matter of urgency to gain readers' attention and persuade them to read on.

Similar to Hyland's (2000) study of 160 book reviews from different disciplines, the study found some evaluative terms cut across disciplines, while other have a preferred status in one or two fields. In this regard, frequently used evaluative adjectives for all eight disciplines include useful, important, and interesting, while detailed and up-to-date are frequently used in the hard sciences. Congruent with Hyland's study, a recent study focusing on adjective and that-clause by Kanoksilapatham (2003) illustrated the adjectives that control that complement clauses are particularly likelihood adjectives (e.g., likely, possible and probable), attitude adjective (i.e., interesting, acceptable, necessary), and factual or certainty adjectives (e.g., impossible, evident, obvious). Those adjectives indicate that these simultaneously occurring features index the author's expression of their agreement, opposition, evaluation, and interpretation of propositions.

In summary, as suggested by previous research, several mechanisms to express writers' evaluative stance have been investigated. This approach can be seen as an attitudinal dimension, including features such as selecting predicate and/or using adjective with that-clause. This style of writing, as explained by Hyland (2002), refers to the ways writers present themselves and convey their judgments, opinions, and commitments. It is the way that writers intrude to stamp their personal authority onto their arguments or step back and disguise their involvement (p. 176).

\section{Discussion Section}

It is agreed by scholars that the Discussion section is one of the most important sections of research articles (e.g., Berkenkotter \& Huckin, 1995; Swales, 1990). Generally, the Discussion section in a research article might stand alone or be included with the Conclusion section. Swales (1990) asserts that the Discussion section is presented as a mirror image of the introduction, reporting major results by trying to move the readers back from the specific information presented in the results section to a more general view of how the results should be interpreted.

Swales and Luebs (2002) examined Discussions from a continuous run of twenty-five articles published in early 1998 in the Journal of Personality and Social Psychology. Their study revealed that the Discussion section strongly advocated the importance or noteworthiness of their findings. Likewise, the Discussion section should provide the writers' comment on 
their main findings. Lewin et al. (2001) also investigated social science research articles dealing with Discussion section. Concerning a general resetting of the research scene, the authors reported the finding using move analysis that basically Discussion section will open with reporting the results of the study and evaluating these findings. Then, the writers of each study mostly will offer the interpretation as well as state implications from the finding gained after having conducted the study.

As clearly seen from the literature mentioned above, Discussion section is of interest for two reasons. First, the Discussion section can be viewed a crucial part of research articles, presenting the results of the study as well as evaluating those results in order to gain the readers' attention to read on and trust their evaluation. Second, a number of reasons are offered to explain difficulties in writing this particular section. For instance, the successful writing of this section requires the knowledge of linguistics and discourse and special care in choosing appropriate linguistic features (Shaw, 1991). Given the importance of the Discussion section and evaluative stance in academic texts, it is needed to explore linguistic devices functioning as an evaluation used by writers in academic research articles in the Discussion section which is the site where the writers should give their evaluation in their findings.

\section{METHODS}

\section{Data Collection and Analysis}

In this section, the corpus systematically compiled by the researcher are exemplified to illustrate how it is sizable and at the same time representative. The factors taken into consideration when designing the corpus of the study are as follows:

\section{Dataset Compilation}

In order to assure that all of the research articles selected in the present study are representative and reliable, and the results of the present study can be generalizable, the following steps need to be taken into account. First, since previous studies on discourse study have shown that disciplinary variations can have influences on rhetorical structure and language use (e.g., Hyland, 2000; Nwogu, 1997; Swales, 1990), to control possible disciplinary variation, the research articles were randomly selected from the top five journals in the field of applied linguistics and English language teaching-English for Specific Purposes (ESP) and System. Then, all of the journals were systematically complied and representatively selected based on the impact factor ${ }^{1}$ released in 2010. Four articles were, thus, systematically selected from each journal, yielding a corpus of 20 research articles of approximately 190,000 words. Next, as the journals differ in the extent of their academic or educational focus-some will combine Discussion section with Conclusion section, only the articles reporting explicitly on the Discussion section in the article from those journals are appreciated.

To analyze the data, frequency analysis was conducted to provide quantitative data for the possible number of linguistic features of evaluative stance, found in the corpus. Subsequently, the semantic reference of the meanings of communicative functions presented by these linguistic features was analyzed qualitatively on the basis of what their functions are in the text.

\section{Inter-coder Reliability Analysis}

It is noted that, due to the semantically driven characteristic of discourse analysis, it is possible that two different individuals

\footnotetext{
1 The impact factor is the average number of times that articles published in a specific journal in the two previous years were cited in a particular year. This figure is from Journal Citation Report (JCR), providing quantitative tools for evaluating journals. It is useful in identifying the significance of absolute citation frequencies.
} 
may demarcate different meanings of linguistic features. This limitation crucially calls for the integration of intercoder reliability analysis, a solution to help boost the strength of the analysis of the study. In this study, three experts in ELT professionals serve as coders to verify that the meanings or communicative functions can be agreed upon across individuals. All of them completed their M.A. either in the United Kingdom or in Thailand. At the time of study, they were the faculty members in the language institute at public and private universities in Thailand. As a part of this procedure, a coding protocol was devised, based on the initial discourse analysis. The coding protocol comprises of the linguistic devices illustrated by examples taken from the corpus.

The coders were trained how to use the coding protocol to carry out discourse analysis. Following training, discussing, and questioning, the coders were asked to independently analyze linguistic devices of five articles. Upon completion, the intercoder reliability was assessed by percentage in order to indicate the satisfactory agreement level between the researcher and each of the three coders. In the present study, the percentage agreement assessed was $87 \%$, indicating the satisfactory agreement level between the researcher and the coders.

\section{FINDINGS AND DISCUSSION}

This following section describes the sets of linguistic features identified in academic corpus, their interpreted communicative functions in discourse, and representative excerpts taken from the corpus to illustrate such co-occurrences.

The corpus revealed that writers used epistemic modality, communication verbs, extraposed 'it', and personal pronouns to express the evaluative stance of the writers towards the thing or the proposition the writers are talking about. The following table illustrates the difference in number of each linguistic feature found in the corpus.

Table 1. Frequency of linguistic features of evaluative stance

\begin{tabular}{|c|c|c|c|}
\hline $\begin{array}{l}\text { Linguistic features } \\
\text { of Evaluative Stance }\end{array}$ & $\begin{array}{l}\text { Frequency } \\
\text { Found in } \\
\text { text }\end{array}$ & Percentages & Example realizations \\
\hline 1. Epistemic modality & 22 & $44 \%$ & $\begin{array}{l}\text { the experimental research papers } \\
\text { in medical journals can be } \\
\text { analysed, } \\
\text { the nine moves identified in the } \\
\text { JRV would seem to fall into }\end{array}$ \\
\hline $\begin{array}{l}\text { 2. Communication } \\
\text { Verbs }\end{array}$ & 10 & $20 \%$ & $\begin{array}{l}\text { the data suggests that, } \\
\text { The results obtained in this } \\
\text { study indicate that }\end{array}$ \\
\hline 3. Extraposed 'it' & 10 & $20 \%$ & $\begin{array}{l}\text { it does become apparent that, } \\
\text { it seems undeniable that } \\
\text { it is important } \mathrm{TO}, \\
\text { it is not easy } \mathrm{TO}\end{array}$ \\
\hline 4. Personal Pronouns & 8 & $16 \%$ & $\begin{array}{l}\underline{I} \text { still find that, we cannot speak, } \\
\text { we are still left with the } \\
\text { important questions }\end{array}$ \\
\hline Total & 50 & $100 \%$ & \\
\hline
\end{tabular}


Table 1 illustrates that the number of times that epistemic modality is used 22 times which is $44 \%$. Communication verbs recur 10 times which is $20 \%$. This figure is equivalent to the recurrence of the use of extraposed ' $i t$ ' with that complement clause, and to clause controlled by predicate and adjective while the recurrence of the use of personal pronouns rank last which amounts to 8 times, and therefore equivalent to $16 \%$ of the total numbers of linguistic features found in the corpus.

From the data shown in Table 1, it can be concluded that the majority of the writers choose to use epistemic modality to express their evaluative stance. Communication verbs and extraposed ' $i t$ ' are the second most frequent choice among these writers. Then, the use of personal pronouns like 'we', 'I', ' $m y$ ' and ' $u$ ' is least frequently used to express their evaluative stance. Based on the assumption that each linguistic feature helps perform an evaluative stance of the writers, the following sections would describe the characteristics of possible variations of the co-occurrence patterns of linguistic features, and the assignment of each type from the analysis in details.

\subsection{Epistemic Modality}

The use of epistemic modality recurs most frequently in the corpus. As Hunston and Thompson (1999) described that evaluative stance is the speaker's or writer's sense of the probability or necessity of a statement, the discourse functions of epistemic modality are considered to express the evaluative stance of the writers (i.e., may, would, and can). The following text samples (1) indicate the authors' attitude towards propositional content by modal auxiliary verbs such as may and could (italicized and underlined).
(1)
a. This study has shown that experimental research papers in medical journals can be analysed

in terms of a conventional schema, consisting of hierarchically ordered knowledge structures referred to as Moves and their constituent elements or Sub-Moves. (RA 4)

b. The DEE system $\underline{\text { may }}$ also account for the tendency for the information contained in Moves 8 and 9 to always occur in the final segments of the text.

(RA 1)

c. Their wishes to have more English lessons could be interpreted as signs that they still needed guidance and consultation from teachers who would teach these lessons. (RA 2)

d. The results obtained in this study indicate that there are nine possible moves which may be realized in typical JRV text.

(RA 1)

e. It may well be that the students would have been rated in exactly the same way as in February, had one or two more entries been taken into account.

(RA 3)

From the text samples shown above, the writers use epistemic modality to present their evaluative stance in different meanings. That is, the assumptions in (b), (d) and (e) which the notion that the proposition after the epistemic modality can probably happen, or assessment of possibilities in (c), or their confidence in the truth of the proposition expressed in the discourse in (a). As Nunan (2004) suggested, modality is the dimension of an utterance which allows the speaker or writer to reveal his or her attitude towards 1) the propositional content or 2) the illocutionary force of an utterance. Accordingly, these reasons can support the findings of the writer's using epistemic modality to reveal their evaluative stance. As clearly seen from the above examples, 
stance is virtually always expressed through the use of epistemic modality, representing the writer's assessment of the truth value or credibility of statement about the world.

Moreover, it is evident that the writers will use epistemic modality when they would like to interpret their analysis or results to draw the generalization in (c) and (d) or show possibilities of their thought in (e). Particularly, the verbs that are usually used in the corpus are interpret, realize and analyze, and most of them are always used in the passive construction. Therefore, it may be interpreted that this feature is a crucial element in the use of epistemic modality in indicating the writers' judgments about validity of their findings and their thought in academic research writing because they recur the most frequently in the corpus and serves several meanings for the authors.

\subsection{Communication Verbs and that clauses}

Another evaluative stance found in academic discourse can be clearly seen by the use of a wide range of different predicates. Most commonly, because of this corpus gained from the Discussion section, communication verbs such as suggest, show and indicate are used to state the results of the study. More interestingly, from the corpus, we can see that this kind of verb would mostly be employed to state the findings with that clause controlled by such a verb. This means that the writers will express their attitude towards the proposition in the that clause and is typically realized by the controlling predicate. The following text samples (2) taken from the corpus illustrate the set of occurring features: communication verbs (italicized) and that clause (underlined).

(2) a. At the time when the research took place, although there had been a general decline in learning English among the informants in comparison with that in China, the data suggests that some learners had been acquiring new motives, knowledge, and beliefs as well as strategies in language learning after being exposed to the new settings.

(RA 2)

b. The results obtained in this study indicate that there are nine possible moves which may be realized in a typical JRV text.

(RA 1)

c. The first analysis, which tries to rate students' strategy use in general, shows that there is a great difference between students. (RA 3)

d. The results obtained in this study show that a typical medical research paper may be made up of eleven schematic units or "Moves", consisting of three each from the Introduction and Methods sections, two from the Results section and four from the Discussion section.

(RA 4)

The use of communication verbs in the Discussion section has a powerful meaning in discourse. That is, writers can persuade their communities to certify their claims as recognized knowledge through a careful, precise presentation of the results; namely, show in (c) indicate and (b). In addition, they may generally mark their claim as a suggestion in (a), and indication-- indicate in (b) and suggest in (a). Moreover, in (c) the writer highlights his findings or supporting information by presenting them with the word 'great difference' revealing the striking difference as hypothesized at the beginning of the study. As advocated by Hyland (2009), these communication verbs or so-called report verbs refer to writing activities, like discuss, suggest, argue. These involve the expression of arguments and allow writers to discursively explore issue while carrying a more 
evaluative element in reporting other authors' work.

Also, the writers express their assumptions by making claim on their result towards the use of epistemic auxiliary 'may' in (b) and (d). According to Hyland (2009), these devices known as hedges have function to withhold complete commitment to a proposition, implying that a claim is based on plausible reasoning rather than certain knowledge. That is, these linguistic devices can indicate the degree of confidence the writer thinks it might be wise to give a claim, while opening a discursive space for the readers to discuss, interpret or negotiate their thought of their findings. In a nutshell, it can be said that with this strategy to indicate the results of the study, the range of communication verbs (e.g., shows, indicate, suggest) are used to indicate the strategy called 'abstract entity' by using inanimate source (the result shows that...) to present the authors' own result of the research. This is congruent with Hyland and Tse's (2004) study claiming that concealing the source of the evaluation, by generalizing the source or attributing responsibility to subjects which cannot be traced to the author, can also be seen as an authorial stance as it represents a conscious decision not to accept direct responsibility for the interpretation which follows.

\subsection{Extraposed 'it', that complement clauses controlled by predicative adjectives, and to complement clauses controlled by adjectives}

Another set of linguistic features cooccurring quite frequently includes extraposed 'it', that complement clauses controlled by predicative adjectives, and to complement clauses controlled by adjectives. While writers almost always refer to their findings first in the Discussion section, from the corpus it shows that almost half of the evaluations were attributed to unidentified source, usually through the use of an 'it' subject.
Therefore, in academic discourse, the extraposed ' $i t$ ' provides a means for the authors to express their comments or attitudes without stating their identification explicit (Hewings \& Hewings, 2002). The following text samples (3) taken from the corpus illustrate the use of extraposed ' $i t$ ' with that complement clauses.

(3) a. it does become apparent that the more successful students use the strategies more frequently, and thus get a higher score according to the rating scale.

(RA 3)

b. Elsewhere (Halbach, 1995) it had become evident that one of the main problems of the weaker students was the selection and/or creation of appropriate, wellfocused follow-up activities, which seems to confirm this impression.

(RA 3)

c. On the other hand, it seems undeniable that it is also the more successful students who find it easier to explain what they have done and thus will get a better score for strategy training (see Skehan, 1989, p. 80, for a similar point).

(RA 3)

Biber et al. (1999) demonstrated that predicate adjectives provide the authors with a means to express their stance, and that compliment clauses controlled by adjectives indicate clearly the expression of the author's stance. Therefore, that complement clauses here are generally known to index information integration to expand the idea-unit. In other words, predicative adjectives are used as heads of that complement clauses, indexing an expression of the writers' stance. That is, syntactically, the writers' stance is given in the main clause, and the propositional information is portrayed in the that complement clause (e.g., it had become evident one of the main problems of the 
weaker students was the selection ...). Also, from the examples text above, the stance towards propositions can be characterized as interpretation, attitude or generalization.

From the corpus of this study, the adjectives that control that complement clauses are particularly factual/certainly adjectives (e.g., evident, apparent), and attitudinal adjectives (e.g., undeniable). This indicates that these co-occurring features index the author's expression of their certainty or confidence in their findings in (a), and certain judgment of propositions in (c).

Similarly, the following text samples (4) from the corpus illustrating the set of co-occurring features are another feature that extraposed ' $i t$ ' co-occurs quite frequently with to complement clauses controlled by predicate.

(4) a. Thus, before drawing any conclusions about students' use of strategies, it is important TO gain further insights into it with the help of other instruments such as direct observation, think-aloud techniques, etc.

(RA 3)

b. Although this result seems to be corroborated by some other studies in the field (for a summary, see Skehan, 1989), it is not easy TO establish which of the two-- language proficiency or strategy use-- comes first since, as Skehan points out, "one can [. ..] argue that learner strategies do not determine proficiency, but are permitted by it" (Skehan, 1989, p. 97).

(RA 3)

c. Thus, it is difficult TO determine whether Moves 2, 3 and 4 inMckinlay's characterization are really separate Moves or subcategories of a single Move.

(RA 3)
The sample texts illustrate the use of extraposed 'it' (bolded), predicative adjectives (italicized), and to clauses controlled by adjectives (capitalized). These features work together to create a text that expresses the author's evaluative stance. It is clear that semantic class of controlling predicative adjectives are evaluative adjectives (e.g., importantexpressing the writer's confidence in their findings in (a)) and ease/difficulty adjectives (e.g., easy, difficult - expressing the difficulty and uncertainty to make a claim or generalization in (b) and (c)). In other words, the co-occurrence pattern of these predicative adjectives and to complement clauses represents the authors' ease or difficulty with (c), and appraisal of ( $a$ and b), propositions in complement clauses.

Taken together, from the examples above, the co-occurrence of these linguistic features (extraposed 'it', that complement clauses controlled by adjectives, predicative adjectives, and to complement clauses controlled by adjectives) index the authors' personal stance towards the propositions in the that/to complement clauses in an impersonal way. That is, their personal stance is back grounded and not directly attributed to specific individuals.

\subsection{Personal Pronouns}

Apart from the extraposed ' $i t$ ' providing a means for the writers to express their comments or attitudes without stating their identification explicitly in the text or discourse, in the corpus of this study, it also reveals the use of pronoun ' $I$ ' and ' $W e$ ', as well as one of possessive case like ' $m y$ ' and 'us'. The following text samples (5) are a typical example illustrating the use of personal pronoun and possessive pronoun (italicized and underlined) in academic discourse.

(5) a. At the same time, $\underline{m y}$ informants also exhibited signs of manipulating crucial elements of 
the social settings and adopting appropriate strategies for their own purposes.

b. However, in spite of these drawbacks, $\underline{I}$ still find that the insights about students' use of strategies provided by the analysis of the diaries are valuable, and that using a rating scale of this type is useful.

(RA 3)

c. Although we cannot speak of a direct correlation between strategy use and academic performance, it does become apparent that the more successful students use the strategies more frequently, and thus get a higher score according to the rating scale.

(RA 3)

d. Having said this, we are still left with the important questions of why JRV texts have the kind of schematic structure identified above and what advantages this structure has for the lay reader attempting to decode the message in a typical JRV text.

(RA 1)

e. This refers $\underline{u s}$ to one of the problems of trying to establish a comparison by analysing a small number of entries (a minimum of only four) from the beginning and end of the course in order to draw some general conclusions as to students' use of strategies.

(RA 3)

The above text samples illustrate the use of personal pronouns which perform the discourse functions. For example, the use of ' $w e$ ' in (d) and ' $I$ ' in (b) signal the presence of researchers in the research article. They also characterize specific discourse contexts where writers want to emphasize their role and responsibility for their claim in research. In Hyland's (2009) words, by marking your views with the first person, you leave readers in no doubt of your stance while claiming credit for what you are saying. It is a powerful way of demonstrating an individual contribution and establishing a claim for priority. In other words, 'we' here in the text (d), and ' $I$ ' in (b) are used when the writers want to stress their personal contribution and their presence in the research article.

Moreover, it is found that the use of we in the sample text (c) refers to the 'writers and readers'. That is, the group of referents of the pronoun 'we' is a larger group of people including the speaker and audience. The speaker's intention in the sentence (c) is to involve the audience in what he is talking about. By using ' $w e$ ', the writers presuppose the readers' background knowledge and ability to follow the argument whereas by using ' $I$ ' referring only to the researcher, it may be that the researcher is confident in and ensure his findings or claim to his target readers. Simply put, regarding the discourse functions, the use of personal pronouns in the corpus all relates to the representation closely linked to the referent of representative or spokesperson of a group.

In addition, the use of possessive case ' $m y$ ' from the corpus can reflect the important role of informants of the study. The writer uses the possessive case to show the relationship and give the importance of the data gained from the participants all the time. It might be said that the use of ' $m y$ ' in the corpus as the writers just show the results from their study only. This means that they do not want to make a big claim when they draw the discussion and conclusion. They would like to confirm their findings using ' $m y$ ' to refer to their results only.

With respect to the style of research writing, the use of pronouns in academic research might not be consistent with the traditional approach which states that the 
style of writing for academic prose should be distant and impersonal way as mentioned earlier (Fortanet, 2004). To discuss the use of personal pronouns in academic research in details, first of all, this style of writing is American style which is quite widely accepted today in modern academic writing. This approach can be used to express the writers' identity in their paper. Therefore, viewing written text as interaction, this linguistic feature can be revealed by analyzing its discourse functions which not only indicate the nature of modern journal articles, but the writers-researchers also emphasize the originality and importance of their research by shortening the distance from readers, and stressing solidarity. Moreover, it can be used to seek the acceptance and recognition of readers, and target academic community. That is why writers put themselves or their presence in the paper and why they perceive their relationship with the readers in the study by using personal pronouns. Consequently, knowledge of the use of personal pronouns is of great value since this may represent a difficulty for the understanding of international students who are not used to seeing this writing style.

\section{CONCLUSION}

This study focuses on the analysis of evaluative functions and stance in Discussion section of research articles. Overall, the analysis of evaluative stance in academic discourse applied in this specialized corpus reveals some sets of cooccurrence of linguistic features including epistemic modality, communication verb with that clause, extraposed 'it', that complement clauses controlled by predicative adjectives, and to complement clauses controlled by adjectives, and personal pronouns contributing to different writers' evaluative stance in academic discourse. Each linguistic feature commonly found in the present study reveals that the writers can express their evaluative stance in academic writing by using some linguistic features to work together as communicative functions in discourse even though it is usually seen as objective and impersonal.

The analysis of evaluative stance as shown by the use of linguistic features reflects how the scholars in the field achieve their communicative functions in the Discussion section. To be precise, the meanings of each linguistic feature represented in the corpus are different. As found in the study, epistemic modality can be used to present the assumption, the assessment of possibilities, and confidence of the writers whereas communication verbs can indicate precise presentation of the results. Extraposed ' $i t$ ' recurs with two features: that complement clauses controlled by predicative adjectives, and to complement clause controlled by adjectives, which express the writers' confidence and feeling of difficulty in making a claim or generalization. Put another way, these two linguistic features can index the authors' personal stance towards the proposition in an impersonal way. On the contrary, the use of personal pronouns is used to refer to both speakers and audience to involve what the article is about, and to reflect the importance of the subjects of the study. This style of writing also shows the identity of authors in the text.

Understanding the choices of linguistic features used in academic discourse provides important information on the evaluative stance that the writer is taking towards the projected subject. The meanings of such linguistic features observed in this paper semantically play an important element in conveying the writer's position on what is being evaluated. From the findings of the present study, it is shown that evaluation is important to discourse for two reasons: it plays a vital role in constructing the ideological basis of a text, thereby locating writer and reader in an ideological space; 
and it plays a vital role in organizing a text. Evaluation on both the autonomous and the interactive planes take part in both functions. However, the corpus investigated in this study is still limited. There should be a clear-cut method to be used in analyzing and specifying linguistic features of evaluative stance, which is better or more practical than the definition proposed by Hunston and Thompson (1999). Moreover, the present study focuses on the function of evaluative stance only of the discussion section of research articles. Therefore, further study is needed to focus more and use the wide range of corpus to gain several types of linguistic features presenting discourse functions.

This research study is pedagogically beneficial in language teaching in general and in particular in the instruction of reading and writing academic research articles in a number of ways. First, the results of this study provide a list of linguistic features used in expressing the evaluative stance of the writers through academic discourse. In this regard, a better understanding of how scholars use linguistic features or lexical-grammatical features to convey attitudinal or evaluative meanings can enable novice and new scholars and advanced students to enhance their writing skills. Second, the findings could shed some light into the awareness of some linguistic features that can empower learners to become proficient academic readers and/or writers. Finally, the study's findings would offer practical implications to advanced language learners who perceive themselves as having difficulty in understanding research articles and teachers interested in pedagogy in reading and writing instruction.

\section{REFERENCES}

Berkenkotter, C. \& Huckin, T. (1995).

Genre knowledge in disciplinary communication: Cognition, culture, power. Hillsdale, New Jersey:

Lawrence Erlbaum.
Biber, D., Johansson, S., Leech, G., Conrad, S., \& Finegan, E. (1999). Longman grammar of spoken and written English. Harlow: Longman.

Craswell, G. (2005). Writing for academic success. Sage Publications: London.

Crismore, A., Markkanen R., \& Steffensen, M. (1993). Metadiscourse in persuasive writing: a study of texts written by American and Finnish university students. Written Communication, 10, 39-71.

Crystal, D. (1997). English as a global language. Cambridge: Cambridge University Press.

Dontcheva-Navratilova, O. (2009). Evaluation in non-native writer's academic discourse: Stance devices. In: Hanušová, S. et al. (Eds.) Research in English Language Teacher Education (pp. 33-42). Brno: Masaryk University.

Fortanet, I. (2004). The use of 'we' in university lectures: Reference and function. English for Specific Purpose, 23, 45-66.

Halliday, M. \& Hasan, R. (1989). Language, context and text: Aspects of language in a social-semiotic perspective. Oxford: Oxford University Press.

Herriman, J. (2000) Extraposition in English: A study of the interaction between the matrix predicate and the type of extraposed clause. English Studies, 81(6), 582-599.

Hewings, M. \& Hewings, A. (2002). "It is interesting to note that..." a comparative study of anticipatory 'it' in student and published writing. Englishfor Specific Purposes, 21, 367-383.

Hunston, S. (2007). Using corpus to investigate stance quantitatively and qualitatively. In Englebretson, R. (Ed.). Stance taking in Discourse (pp. 27-48). Amsterdam and Philadelphia: John Benjamins. 
Hunston, S., \& Thompson, G. (1999). Evaluation in Text: Authorial Stance and the Construction of Discourse. Oxford: Oxford University Press.

Hunston, S. \& Thompson, G. (2000) Evaluation: An introduction. In Hunston, S. and G. Thompson (Eds.). Evaluation in Text. Authorial Stance and the Construction of Discourse (pp. 1-27). Oxford: Oxford University Press.

Hyland, K. (1999). Disciplinary discourse: Writer stance in research articles. In Candlin, C. \& Hyland, K. (Eds.). Writing; texts, processes and practices (pp. 9-121). Harlow: Addison Wesley Longman.

Hyland, K. (2000). Disciplinary discourses. Harlow UK: Longman.

Hyland, K. (2002). Authority and invisibility: Authorial identity in academic writing. Journal of Pragmatic, 34, 1091-1112.

Hyland, K. (2005a). Stance and engagement: A model of interaction in academic discourse. Discourse Studies, 7(2), 173-192.

Hyland, K. (2005b). Metadiscourse. London: Continuum.

Hyland, K. (2008). 'As can be seen: Lexical bundles and disciplinary variation.' English for Specific Purposes, 27, 4-21.

Hyland, K. (2009). Writing in the disciplines: Research evidence for specificity. Taiwan International ESP Journal. 1(1), 5-22.

Hyland, K., \& Tse, P. (2004).

Metadiscourse in academic writing: A reappraisal. Applied Linguistics, 25(2), 156-177.

Ivanic, R. (1998). Writing and identity; The discoursal construction of identity in academic writing. Amsterdam: John Benjamins Publishing Company.
Jacobs, R. (1995). English syntax: A grammar for English language professionals. Oxford: Oxford University Press.

Kanoksilapatham, B. (2003). Corpus-based investigation of biochemistry research articles: Linking move analysis with multidimentional analysis. Unpublished dissertation. Georgetown University: Washington, D.C.

Kanoksilapatham, B. (2005). Rhetorical structure of biochemistry research articles. English for Specific Purposes, 24, 269-292.

Lewin, B. A., Fine, J., \& Young, L. (2001). Expository discourse: A genre-based approach to social science research texts. London: Continuum.

Martin, J. R. (1997). Analyzing genre: Functional parameters. In F. Christie and J. R. Martin (Eds.), Genre and institutions (pp. 3-39). London: Continuum.

Nwogu, N. K. (1997). The medical research paper: structure and functions. English for Specific Purposes, 16(2), 119-138.

Nunan, D. (2004). Introducing to discourse analysis. Quarry Bay: The Central Printing Press Ltd.

Rodman, L. (1991). Anticipatory IT in scientific discourse. Journal of Technical Writing and Communication, 21(1), 17-27

Shaw, P. (1991). Science research students' composing processes. English for Specific Purposes, 10(3), 189-206.

Swales, J. (1990). Genre Analysis. Cambridge: Cambridge University Press.

Swales, J. M. \& Luebs, M. A. (2002). Genre analysis and the advanced second language writer. In E. Barton \& G. Stygall (Eds.), Discourse Studies in Composition (pp. 135-154). Cresskill: Hampton Press. 